\title{
Ritual Pethik Pari sebagai Pembentukan Ulang Individualitas Petani : Studi tentang Budaya Pethik Pari di Desa Dukuh Dempok, Wuluhan, Kabupaten Jember
}

\author{
Fitrotin Nisa', Sofia Nabilla Bayani, Adellisa Wardani, Dinda Clarita Salsadillah \\ Program Studi Sosiologi \\ Fakultas Ilmu Sosial dan Ilmu Politik \\ Jalan Kalimantan No.37 Jember \\ Universitas Jember \\ nisafitrotin14@gmail.com; sofianabillabayani13@gmail.com; adellisa.wardani@gmail.com; \\ claritadinda10@gmail.com
}

\begin{abstract}
The Pethik Pari tradition is a tradition of the Javanese farming community. This tradition is in the form of a series of selamatan ritual performed as a form of gratitude of the farmers to God Almighty for abundant sustenance through good harvests. The Pethik Pari ritual used to be carried out by Dukuh Dempok Village farmers individually in their homes by simply carrying out a simple slametan. But now, the ritual procession is changing and carried out jointly by farmers in the fields by carrying out slametan, Wayang's performances, and fishing together in the rice fields. With the change in the implementation of the ritual procession, making the Pethik Pari ritual a re-establishment of the individuality of peasants in Dukuh Dempok Village. The ritual tradition of Pethik Pari itself, is also a symbol of the Javanese peasant community that there is a belief in the existence of Dewi Sri as a goddess of prosperity. This research uses descriptive qualitative method with a case study approach. Data was collected through in-depth interviews with informants from the head of the farmers' groups and Dukuh Dempok Village farmers. The focus of this study was to determine the reestablishment of the individuality of farmers in Dukuh Dempok village, Wuluhan, Jember, East Java.
\end{abstract}

Keywords: Pari Pethik Tradition, Individuality, Farmers.

Tradisi Pethik Pari merupakan tradisi masyarakat petani Jawa. Tradisi ini berupa serangkaian ritual selamatan yang dilakukan sebagai salah satu wujud rasa syukur para petani kepada Tuhan Yang Maha Esa atas rezeki yang melimpah melalui hasil panen yang bagus. Ritual Pethik Pari dahulu dilakukan oleh para petani Desa Dukuh Dempok secara individual di rumah masing-masing dengan hanya melaksanakan slametan secara sederhana. Namun saat ini, prosesi ritual tersebut mengalami perubahan dan dilakukan secara bersama-sama oleh para petani di sawah dengan melaksanakan slametan, pagelaran Wayang, dan memancing bersama di sawah. Dengan adanya perubahan pelaksanaan prosesi ritual, menjadikan ritual Pethik Pari tersebut sebagai pembentukan ulang individualitas petani di Desa Dukuh Dempok. Tradisi ritual Pethik Pari sendiri, juga merupakan simbol dari masyarakat petani Jawa bahwa terdapat suatu kepercayaan akan adanya Dewi Sri sebagai dewi kemakmuran. Penelitian ini menggunakan metode deskriptif kualitatif dengan pendekatan studi kasus. Data dikumpulkan melalui teknik wawancara mendalam dengan informan ketua kelompok tani dan petani Desa Dukuh Dempok. Fokus penelitian ini untuk mengetahui pembentukan ulang individualitas petani yang ada di Desa Dukuh Dempok, Kecamatan Wuluhan, Kabupaten Jember, Jawa Timur.

Kata Kunci : Tradisi Pethik Pari, Individualitas, Petani.

\section{Pendahuluan}

Masyarakat Jawa terkenal memiliki banyak tradisi yang masih sangat kental dan terus dilakukan yang mencangkup tentang nilai-nilai dalam kehidupan baik nilai religius, sosial maupun nilai budaya dalam hidup. Termasuk pada masyarakat Desa Dukuh Dempok Kecamatan Wuluhan Kabupaten Jember yang memilki tradisi "Pethik Pari" yang dilakukan oleh masyarakat petani. Dimana Pethik Pari dilakukan sebagai ungkapan rasa syukur pada Tuhan yang telah memberikan rezeki lewat tanaman hasil panen padi mereka. Pethik Pari sendiri merupakan tradisi dimana masyarakat melakukan sebuah syukuran bersama di sawah ketika akan melakukan panen padi. Sehingga mereka dapat berinteraksi dan jalinan kekeluargaan mereka semakin erat. Masyarakat desa Dukuh Dempok mayoritas 
warganya beragama Islam. Namun dalam tradisi pethik pari ini tidak memandang perbedaan agama semua kalangan dari berbagai agama, berbagai profesi maupun berbagai usia dapat ikut merayakan tradisi Pethik Pari ini.

Dahulu Pethik Pari ini hanya dilaksanakan dirumah-rumah dengan mengadakan selamatan dan menyuguhkan beberepa makanan kepada tetangga yang diundang oleh pemilik rumah. Namun dengan usulan salah satu ketua kelompok tani, yakni Bapak Edi yang mengusulkan agar kegiatan selamatan Pethik Pari dilaksanakan di sawah secara bersamasama. Menurut keterangan beliau usulan tersebut terinspirasi ketika beliau melihat pertanian di Amerika yang menurutnya sangat luar biasa mekipun jumlah petani sedikit dan lahannya luas, namun disana petani sangat makmur karena mereka bersatu sehingga banyak lembaga-lembaga yang melindungi petani. Sejak tahun 2004 beliau pulang dari Amerika, sampai tahun 2020 sudah terhitung selama 16 tahun selamatan Pethik Pari ini dilaksanakan secara bersama-sama di sawah. Dalam tradisi Pethik Pari ada berbagai istilah dalam prosesi kegiatannya, antara lain entas-entas sawah, tabur rujak, lalu kegiatan methik. Istilah entas-entas sawah yaitu kegiatan yang dilaksanakan setelah selesai menanam padi berupa selamatan. Kemudian kegiatan tabur rujak, memilki filosofi bahwa buah yang sudah bercampur menjadi rujak yang manis yang ditabur pada pojok sawah akan dimakan oleh hewan atau hama sehingga mereka tidak akan mengganggu dan memakan padi mereka. selanjutnya methik yaitu memanen atau memetik padi yang sudah siap dipanen. Pada pengujung prosesi Pethik Pari, bisanya akan melaksanakan pagelaran Wayang kulit untuk menghibur masyarakat. Wayang kulit dipilih karena diharapakan bukan hanya sebagai tontonan tetapi juga sebagai tuntunan untuk kehidupan.

Selain acara pertujukan Wayang kulit, masyarakat juga melaksanakan acara mancingan yaitu memancing ikan di sungai di sawah. Biaya untuk melaksanakan tradisi Pethik Pari diperoleh dengan sistem iuran oleh masyarakat petani setiap satu bulan sekali. Pethik Pari ini merupakan tradisi masyarakat petani Jawa, sehingga bukan hanya warga masyarakat desa Dukuh Dempok yang merayakannya. Melainkan juga masyarakat petani Jawa dari berbagai kota seperti kota Banyuwangi misalnya. Namun dengan istilah atau penyebutan nama acara yang berbeda, tergantung dengan daerah masing-masing. Selamatan Petik Pari ini menjadi sebuah wadah bagi semua golongan masyarakat yang berbeda baik berbeda agama, profesi maupun usia untuk berkumpul bersama dalam rangka mengucapkan rasa syukur atas rezeki melimpah dari hasil panen padi para petani. Meskipun terkadang para petani mengalami kerugian atau gagal panen mereka tetap melakukan tradisi tersebut, karena mereka percaya bahwa seberapapun besarnya rezeki yang diperoleh harus tetap disyukuri.

Adanya ritual Pethik Pari ini juga menjadi salah satu upaya untuk melestaraikan tradisi Jawa yang merupakan warisan nenek moyang yang sudah dilakukan secara turun temurun dan tidak pernah ditinggalkan oleh masyarakat desa Dukuh Dempok. Dalam hal ini peneliti tertarik untuk mengakaji lebih dalam tentang bagaimana ritual Pethik Pari sebagai pembentukan ulang individualitas petani dan interaksi simbolik didalam ritual Pethik Pari.

\section{Tujuan}

Berdasarkkan uraian di atas penelitian ini ingin mengkaji tentang ritual Pethik Pari sebagai Pembentukan Ulang Individualitas Petani: Studi tentang Budaya Pethik Pari di Desa Dukuh Dempok, Wuluhan, Kabupaten Jember. Dimana ritual Pethik Pari ini merupakan budaya Jawa yang harus tetap dilestarikan di zaman modern ini. Tujuan dari penelitian ini yaitu ada tiga. Yang pertama, mendeskripsikan dan menganalisis proses ritual Pethik Pari. Kedua, mendeskripsikan dan menganalisis makna ritual Pethik Pari. Dan ketiga, mendeskripsikan dan menganalisis interaksi simbolik pada ritual Pethik Pari di Desa Dukuh Dempok, Kecamatan Wuluhan, Kabupaten Jember.

\section{Metode Penelitian}

Penelitian ini menggunakan metode penelitian kualitatif deskriptif. Dilakukan di Desa Dukuh Dempok, Kecamatan Wuluhan, Kabupaten Jember pada bulan Maret 2020. Pada penelitian ini, peneliti menggunakan metode purposive sampling untuk menentukan informan guna mencari sumber data. Purposive sampling adalah cara dalam menentukan sampel berdasarkan suatu tujuan atau pertimbangan tertentu terlebih dahulu. Jadi, pengambilan sumber informasi (informan) berdasarkan pada maksud yang sebelumnya telah ditetapkan (Yusuf, 2014). 
Teknik pengumpulan data yang digunakan yaitu observasi, wawancara, dan dokumentasi. Observasi merupakan cara mengumpulkan data secara langsung di lapangan (Raco, 2013). Teknik pengumpulan data observasi ini dilakukan untuk mengamati kondisi lingkungan tempat informan dan aktivitas informan atau masyarakat petani Dukuh Dempok dalam keseharian. Wawancara dilakukan untuk mencari dan menggali informasi mengenai budaya pethik pari di desa Dukuh Dempok. Wawancara dilakukan pada informan yaitu ketua kelompok tani dan masyarakat. "Dokumentasi adalah sebuah metode untuk mengumpulkan bahan-bahan dalam bentuk dokumen yang relevan dengan tema penelitian" (Masrizal, 2019). Metode dokumentasi dipakai untuk mencari kelengkapan data atau informasi yang relevan untuk mendukung penelitian ini. Penelitian ini menggunakan teknik pengumpulan data dengan mencari untuk mendapatkan informasi dari sumber tertulis, seperti buku, arsip, jurnal, laporan, dan semacam literatur lainnya yang berkaitan dengan penelitin ini.

Pada penelitian ini peneliti memilih Desa Dukuh Dempok sebagai tempat penelitian. Desa Dukuh Dempok merupakan sebuah desa di Kecamatan Wuluhan, yang memiliki jarak tempuh kurang lebih $0,5 \mathrm{~km}$ dan jarak tempuh kurang lebih $30 \mathrm{~km}$ ke Kabupaten Jember. Secara geografis Desa Dukuh Dempok memiliki luas wilayah $1.262,684$ ha. Dengan kondisi tanah yang baik untuk bercocok tanam dan berkebun, sehingga dapat dilihat bahwa seperempat lebih dari wilayah di Desa Dukuh Dempok adalah persawahan dan tegalan (kebun). Mayoritas masyarakat penduduknya memiliki mata pencaharian sebagai petani.

Secara kultur-historis, masyarakat Desa Dukuh Dempok berasal dari penduduk migran yaitu Yogyakarta, Solo, Ponorogo, Ngawi, Malang dan Kediri. Sehingga tidak salah jika ditemukan kesenian dari daerah lain yang berkembang dan dilestarikan di daerah tersebut, seperti: reog, wayang, dan methik pari (selametan menjelang panen), dan lain-lain.

\section{Tinjauan Pustaka}

\section{Tinjauan tentang Masyarakat dan Kebudayaan}

Menurut Selo Soemardjan dalam Soerjono Soekanto (2006), masyarakat adalah orang-orang yang hidup bersama yang menghasilkan kebudayaan dan mereka mempunyai kesamaan wilayah, identitas, mempunyai kebiasaan, tradisi, sikap, dan perasaan persatuan yang diikat oleh kesamaan. (Soekanto, 2006) Dan menurut Mac Iver dan Page dalam Soerjono Soekanto (2006), masyarakat adalah suatu sistem dari kebiasaan, tata cara, dari wewenang dan kerja sama antara berbagai kelompok, penggolongan, dam pengawasan tingkah laku serta kebiasaankebiasaan manusia. (Soekanto, 2006)

Kebudayaan (culture) menurut kamus sosiologi adalah keseluruhan pengetahuan manusia sebagai makhluk sosial yang digunakan untuk memahami lingkungan serta pengalamannya dan yang menjadi pedoman tingkah lakunya. (Dani, 2016) Menurut E.B Taylor dalam Soerjono Soekanto(2007), kebudayaan adalah kompleks yang mencakup kepercayaan, kesenian, moral, hukum, adat istiadat, dan kebiasaan lain serta kemampuan-kemampuan yang didapatkan oleh manusia sebagai anggota masyarakat. (Soekanto, Sosiologi Suatu Pengantar, 2007) Dan menurut ilmu antropologi, kebudayaan adalah keseluruhan sistem gagasan, tindakan dan hasil karya manusia dalam rangka kehidupan masyarakat yang dijadikan milik diri manusia dengan belajar. (Koentjaraningrat, 2009)

Dari definisi masyarakat dan kebudayaan diatas dapat ditarik kesimpulan bahwa antara masyarakat dan kebudayaan memiliki keterikatan yang tidak dapat dipisahkan. Dimana kebudayaan terbentuk dari sekumpulan manusia yang disebut sebagai masyarakat, yang saling berinteraksi sehingga menghasilkan suatu kompleks kebiasaan yang sama yang disebut sebagai budaya.

\section{Tinjauan tentang Budaya Petani}

Menurut Firth dalam tulisan Sasongko, mendefinisikan petani sebagai orang yang menanam tanaman pangan dan memelihara hewan ternak. Thorner mendefinisikan petani dengan menitikberatkan kepada sistem ekonominya, yaitu sebagai ekonomi pertanian petani adalah unit yang mampu memberi makan diri mereka sendiri dan juga memberi makan pada orang kota dengan memproduksi dan melakukan pertukaran, yang unit produksinya adalah keluarga maupun unit yang lebih besar. (Sasongko, 2006) Masyarakat petani merupakan sebuah hubungan yang antar manusia yang kehidupannya bergantung pada hasil pertanian dan memiliki karakteristik tempat tinggal di pedesaan. Menurut Shanin, masyarakat petani pengusaha tani kecil yang dengan bantuan 
peralatan sederhana dan tenaga kerja dari kalangan keluarga, memproduksi terutama untuk mencukupi kebutuhan konsumsi mereka sendiri dan untuk memenuhi kewajiban terhadap pemegang kekuasaan politik dan ekonomi. (Shanin, 1975)

Kehidupan masyarakat petani yang memiliki karakteristik tinggal di pedesaan, memiliki polapola kelakuan yang dalam konteks kehidupan desa sering dipertukarkan dengan istilah yang diesbut tradisi budaya atau adat istiadat. Menurut Kluckhohn dalam Koentjaraningrat (1979), semua pola-pola kelakuan dalam semua kebudayaa di dunia pada dasarnya menyangkut lima masalah pokok dalam kehidupan manusia, yaitu mengenai (1) hakikat hidup manusia; (2) hakikat dan karya manusia; (3) hakikat kedudukan manusia dalam ruang dan waktu; (4) hakikat dan kedudukan manusia dengan alam sekitarnya; dan (5) hakikat dan hubungan manusia dengan sesama manusia. (Koentjaraningrat,

Masalah-masalah Pembangunan: Bunga Rampai Antropologi Terapan, 1979)

\section{Tinjauan tentang Makna Simbolik Tradisi Budaya Pethik Pari \\ 1) Teori Agama Jawa Clifford Geertz}

Cliford Geertz dalam bukunya Agama Jawa membagi masyarakat jawa kedalam tiga golongan, yaitu Abangan, Santri, dan Priyayi. Golongan Abangan merupakan masyarakat yang menitikberatkan pada aspek animisme dan sinkretisme Jawa, yang menurut Geertz diterapkan pada kebudayaan orang desa yaitu para petani. Salah satu contoh pola tradisi yang masih diterapkan golongan Abangan dalam kehidupannya adalah tradisi slametan. Golongan Santri merupakan kaum yang menekankan pada Islam dari sinkretisme dan umumnya dihubungkan dengan elemen pedagang serta dengan elemen tertentu di kalangan petani. Pola ritual yang dilakukan golongan Santri yaitu sembahyang, sholat jum'at, dan puasa. Dan terakhir golongan Priyayi, menekankan pada aspek Hindu dan berkaitan dengan birokrasi pemerintah yang diwakili oleh pegawai sipil. Golongan Priyayi lebih menitikberatkan pada elemen Hinduisme, tidak seperti Abangan pada elemen animisme dan sinkretisme, juga tidak seperti Santi pada elemen Islam. (Geertz, 2013)

Dari penjelasan tersebut, masyarakat Desa Dukuh Dempok yang mayoritas adalah petani dan masih melaksanakan tradisi Jawa Pethik Pari yang berupa upacara selametan, merujuk pada golongan
Abangan. Meski demikian, selametan Pethik Pari yang dilaksanakan oleh para petani Desa Dukuh Dempok juga tidak terlepas dengan ajaran agama Islam karena mayoritas petani Desa Dukuh Dempok ialah menganut agama Isam.

\section{2) Teori Interaksionalisme Simbolik}

Interaksi simbolik berdasarkan prespektif interaksionalis, menganggap setiap individu di dalam masyarakat memiliki esensi kebudayaan, berinteraksi di tengah sosial masyarakatnya, dan menghasilkan makna buah pikiran yang disepakati secara kolektif. Teori interaksi simbolik menekankan pada hubungan antara simbol dan interaksi. (Ardianto, 2007) Terdapat tujuh asumsi terkait Interaksi Simbolik menurut George Herbert Blumer, yaitu (1) manusia bertindak terhadap orang lain berdasarkan makna yang diberikan orang lain pada mereka; (2) makna diciptakan dalam interaksi antar manusia; (3) makna dimodifikasi melalui sebuah proses interpretif; (4) individu-individu mengembangkan konsep diri melalui interaksi dengan orang lain; (5) konsep diri memberikan sebuah motif penting untuk berperilaku; (6) orang dan kelompok-kelompok dipengaruhi oleh proses budaya dan sosial; (7) struktur sosial dihasilkan melalui interaksi sosial. (Siregar, 2011)

Dalam buku Sosiologi Pengetahuan Permaradigma Ganda, Goerge Ritzer mengatakan bahwa manusia hidup dalam suatu lingkungan simbol-simbol. Manusia memberikan tanggapan terhadap simbol-simbol itu seperti juga ia memberikan tanggapan terhadap rangsangan yang bersifat fisik. (Ritzer, 2016) Manusia adalah animal symbolicum, yang berarti bahwa pemikiran dan tingkah laku simbolis merupakan ciri yang betulbetul khas manusiawi dan bahwa seluruh kemajuan kebudayaan manusia mendasarkan diri pada kondisi-kondisi itu. (Endraswara, 2006) Menurut Turner dalam Endraswara (2006), menyatakan bahwa simbol adalah unit atau bagian terkecil dalam ritual yang mengandung makna dari tingkah laku ritual yang bersifat khusus. (Endraswara, 2006) Tradisi slametan Pethik Pari yang dilaksanakan oleh masyarakat petani Desa Dukuh Dempok, Wuluhan, Jember merupakan tradisi yang tak terlepas dari simbol-simbol didalamnya, baik dari prosesi slametan yang dilakukan maupun kelengkapan seperti sesajen dan sebagainya. Tradisi Pethik Pari sendiri, juga merupakan simbol dari masyarakat petani Jawa bahwa terdapat suatu 
kepercayaan akan adanya Dewi Sri sebagai dewi kemakmuran.

\section{Pembahasan}

\section{Sejarah Pethik Pari di Desa Dukuh Dempok, Wuluhan}

Tradisi Pethik Pari merupakan salah satu tradisi Jawa yang masih dipertahankan sampai saat ini, khususnya oleh masyarakat petani. Karena sebagian orang Jawa meyakini jika melaksanakan tradisi tersebut maka mereka akan diberikan keselamatan oleh Tuhan dalam penggarapan lahan pertaniannya, dijauhkan dari berbagai penyakit dan hama serta mendapatkan hasil panen padi yang melimpah. Ritual Pethik Pari telah dilaksanakan secara turun-temurun oleh masyarakat Jawa di daerah Jember. Ritual ini berupa serangkaian acara yang dilakukan ketika musim tanaman padi hingga masa panen tiba. Masyarakat Jawa memiliki kepercayaan bahwa tanaman padi dianggap sebagai simbol dari kemakmuran yaitu Dewi Sri sebagai Dewi Kemakmuran. Ritual Pethik Pari juga diungkapkan sebagai rasa syukur atas kebaikan Dewi Sri yang dianggap sebagai Dewi Padi. Dewi Sri juga dianggap sebagai Dewi Kesuburan tanaman lainnya seperti buah buahan, pisang, kelapa dan lainnya. Mitos lainnya Dewi Sri dianggap sebagai orang yang pertama kali menanam padi di Jawa.

Ritual Pethik Pari sudah jarang sekali di temukan di masyarakat modern seperti jaman sekarang. Tetapi masyarakat di Desa Dukuh Dempok ini masih mengadakan ritual Pethik Pari ini. Ritual pethik pari ini dilaksanakan di Dusun Purwojati, Desa Dukuh Dempok, Kecamatan Wuluhan, Kabupaten Jember setiap satu tahun sekali. Menurut keterangan ketua kelompok tani Margi Rahayu, Bapak Edi menjelaskan bahwa berdasarkan kondisi geografisnya Jember dibagi menjadi dua, yaitu wilayah utara rel kereta api yang mayoritas penduduknya adalah suku JawaMaduraan, dan wilayah selatan rel kereta api yang mayoritas penduduknya adalah suku JawaMataraman. Desa Dukuh Dempok berada di wilayah selatan rel kereta api, dimana wilayah selatan ini memiliki kondisi tanah yang sangat subur sehingga banyak terdapat lahan sawah yang ditanami tanaman padi. Mayoritas dari masyarakat Desa Dukuh Dempok ialah suku Jawa-Mataraman. Sehingga tidak mengherankan apabila masyarakat petani Desa Dukuh Dempok memiliki tradisi
Pethik Pari yang masih dilaksanakan hingga saat ini.

Perayaan tradisi pethik pari awalnya dilaksanakan di tiap-taip rumah dengan mengadakan selamatan sederhana dan membagikan rezeki kepada tetangga berupa makanan yang terdiri dari nasi tumpeng, ingkung atau ayam panggang, urap dan lauk pauk lainnya sesuai dengan kemampuannya tuan rumah. Namun atas usulan ketua kelompok Margi Rahayu Dukuh Dempok yakni Bapak Edi, sekarang prosesi kegiatan selamatan Pethik Pari dilakukan secara bersama-sama oleh para petani di sawah. Berdasarkan keterangan beliau, usulan tersebut terinspirasi ketika beliau melihat pertanian di Amerika yang menurutnya sangat luar biasa meskipun jumlah petani sedikit dengan lahan luas, namun petani di Amerika sangat makmur karena banyak lembaga-lembaga yang melindungi para petani. Tradisi Pethik Pari yang dilakukan secara bersama oleh para petani di sawah, sudah dilaksanakan selama 16 tahun terakhir. Pertama kali yaitu pada tahun 2004 setelah Pak Edi pulang bekerja dari Amerika.

Menurut keterangan Bapak Edi, usulan tersebut beliau sampaikan pada saat mengikuti kegiatan perkumpulan kelompok tani Margi Rahayu Dukuh Dempok yang beliau pimpin tersebut. Ternyata usulan tersebut memperoleh respon yang baik dari masyarakat dan banyak anggota kelompok yang setuju jika kegiatan Pethik Pari dilakukan bersama-sama di sawah. Menurut mereka akan lebih ramai karena banyak masyarakat yang berantusias dan juga tidak mengurangi kesakralannya. Anggota kelompok tani juga tidak merasa keberatan dengan mengeluarkan biaya iuran sebesar Rp 20.000,00 setiap satu bulan sekali untuk melangsungkan acara tradisi Pethik Pari.

\section{Langkah-langkah Tradisi Pethik Pari}

Prosesi Pethik Pari dilakukan melalui tiga tahapan, tahap yang pertama yaitu entas-entas sawah atau tutup tanam yang dilaksanakan ketika setelah selesai menanam padi. Entas-entas sawah dilaksanakan dengan selamatan yang bertujuan agar padi yang telah ditanam dijauhkan dari segala macam hama dan penyakit.

Kedua yaitu rujak-an atau ngrujak-i. Ketika padi mulai berbuah dan hendak menguning, masyarakat desa Dukuh Dempok akan memberikan rujak yang dinamakan rujak ceprot yang isinya terdiri dari berbagai jenis buah-buahan, mulai dari nangka, tebu, kedondong, nanas, mangga yang 
dideplok atau ditumbuk menjadi satu dengan ditambahkan gula merah. Dan selanjutnya rujak ceprot tersebut akan disebar atau ditaburkan pada tanaman padi di sawah. Tujuan dari semua prosesi ngrujak- $i$ ini adalah sebagai simbol untuk memberikan persembahan kepada Dewi Sri yang merupakan Dewi kemakmuran atau Dewi pangan padi agar hasil panen yang akan diperoleh nantinya. Karena padi diibaratkan sebagai manusia, yang dalam budaya Jawa juga terdapat tradisi ngrujak pada acara pithonan untuk ibu hamil yang memasuki usia kandungan tujuh bulan kehamilan. Namun menurut penjelasan Pak Edi, makna sesungguhnya yang terkandung adalah rujak ceprot yang memiliki rasa manis dan asam yang disebar atau ditaburkan pada tanaman padi akan mengundang serangga yang ada disawah untuk datang sehingga tidak mengganggu tanaman padi para petani.

Ketiga, setelah prosesi ngrujak-i, yaitu tahap methik dan selamatan yang dilaksanakan kurang lebih satu minggu sebelum panen raya berlangsung. Dimana methik merupakan acara simbolis yang memiliki filosofi untuk membawa pulang padi hasil panen para petani, yang dalam istilah orang Jawa disebut mboyong Dewi Sri atau mengajak pulang Dewi Sri ke tempat lumbung padi. Acara methik dilakukan secara simbolis dengan memetik padi dari empat sudut petak sawah yang sembari mengucapkan do'a syukur sesuai agama dan kepercayaan masing-masing bahwa padi tersebut baik, telah dijauhkan dari segala hama dan penyakit. Kata pethik dan methik memilki arti yang sama yaitu memetik. Pari memiliki arti padi. Kata Pethik Pari memiliki arti memetik padi. Selametan Pethik pari ini dilakukan untuk mendapatkan keselamatan dalam penggarapan, mendapatkan hasil panen yang bagus serta lahan pertanian dijauhkan dari hama dan penyakit.

Pada tahap terakhir yaitu methik tersebut, merupakan acara puncak dari prosesi ritual Pethik Pari. Selain melaksanakan mboyong pari, masyarakat akan melakukan beberapa acara lain yaitu selamatan, melangsungkan pagelaran wayang, dan memancing ikan di sawah. Acara selamatan dilaksanakan oleh masyarakat di sawah. Masyarakat khususya para petani akan membawa makanan yang terdiri dari nasi tumpeng, ayam panggang, urap, dan lauk-pauk lainnya. Perlengkapan ritual selamatan lainnya seperti dupa, bunga, jenang abang dan jenang putih juga turut dibawa ke sawah. Perlengkapan tersebut tidak memiliki tujuan lain, seperti kepercayaan kepada roh-roh ghaib dan hanya sebagai pelengkap agar sesuai dengan tradisi Jawa yang dilakukan oleh orang-orang terdahulu. Namun perlengkapan tersebut memiliki makna simbol, diantaranya dupa yang memiliki aroma harum memberikan nuansa ketenangan dan kekhusyukan dalam berdo'a, serta bunga yang juga memiliki aroma harum dan dengan bentuk keindahan mencerminkan kecantikan Dewi Sri. Setelah sesepuh desa atau orang yang diamanahi untuk membacakan do'a dengan bahasa Jawa dan sesuai ajaran Islam sudah selesai, maka acara selamatan dilanjutkan oleh masyarakat dengan makan bersama-sama di sawah. Selametan biasa ini dilakukan diwaktu pagi hari sekitar pukul 10.00 waktu setempat.

Kemudian setelah melangsungkan acara selamatan, masyarakat melanjutkan acara methik dengan kegiatan mancing-mancingan yaitu memancing ikan di sungai di dekat sawah. Masyarakat dari berbagai kalangan, mulai dari anak-anak hingga orang tua selesai makan tumpeng akan tetap berkumpul disawah untuk memancing ikan yang sebelumnya sudah disiapkan. Sebanyak satu kwintal ikan dengan harga kisaran Rp 1.500,00 per ekor dengan berbagai jenis ikan, dilepaskan di sungai dekat sawah.

Dan Acara terakhir yaitu pagelaran Wayang kulit dimalam harinya. Tujuan dilaksanakannya pagelaran Wayang kulit adalah agar pesan-pesan yang terkandung didalam cerita Wayang kulit dapat dijadikan tuntunan bagi masyarakat. Wayang kulit diharapkan tidak hanya sebagai tontonan saja, tetapi dapat menjadi tuntunan masyarakat dalam menjalani kehidupan. Selain itu, tujuan mengapa pagelaran Wayang kulit yang dipilih, yaitu untuk tetap melestarikan budaya Jawa. Mengenalkannya kepada anak-anak dan kaum muda masyarakat Desa Dukuh Dempok agar tidak melupakan budayanya. Pagelaran Wayang kulit dilaksanakan semalam suntuk hingga menjelang dini hari.

\section{Makna atau Alasan Ritual Pethik Pari di Wuluhan}

\subsection{Rasa Syukur kepada Tuhan Yang Maha Esa}

Ritual Pethik Pari merupakan bentuk ucapan syukur para petani kepada Tuhan, setelah sekian lama menunggu mulai dari awal tanam hingga panen raya yang menghasilkan rezeki berlimpah. Sesuai dengan apa yang dijelaskan oleh informan Pak Edi, sebagai ketua kelompok tani Desa Dukuh Dempok: 
"Wong sing paling mulyo uripe wong sing paling ngucapno syukur karo sang maha kuoso."

"Orang yang paling bahagia adalah orang yang selalu mengucapkan syukur kepada Tuhan Yang Maha Esa."

Menurut Pak Edi falsafah tersebut sebagai pegangan kenapa para petani desa Dukuh Dempok masih melaksanakan ritual Pethik Pari hingga saat ini. Sebab para petani memiliki keyanikan seberapapun rezeki yang diterima melalui panen, harus bersyukur kepada Tuhan Yang Maha Esa. Ritual Selamatan Pethik Pari ini dilaksanakan oleh masyarakat Wuluhan juga sebagai simbol puji syukur pada Tuhan karena telah diberi hasil padi melimpah dari bumi atau laham pertanian mereka. Kebiasaan ini telah mengakar kuat pada masyarakat Wuluhan dan sulit untuk dirubah.

\subsection{Untuk Mempererat Tali Persaudaraan}

Selain memiki makna sebagai ungkapan terimakasih atau rasa syukur kepada Tuhan, selametan Pethik Pari juga memiliki makna untuk mempererat tali persaudaraan baik antar tetangga di sawah maupun tetangga dirumah. Mengingat dalam pelaksanaan Pethik Pari dahulu dilakukan di rumah masing-masing dan sekarang dilakukan bersama-sama di sawah. Hal tersebut terlihat pada saat acara methik yang terdiri dari serangkaian acara yaitu selamatan, juga acara yang berisi hiburan seperti mancing-mancingan dan Wayang kulit, dimana yang datang bukan hanya para tetangga petani di sawah melainkan seluruh warga yang berminat untuk ikut serta dan menonton. Sehingga dengan adanya Pethik Pari dapat mempererat persaudaraan antar warga desa Dukuh Dempok karena setiap tahunnya melalui tradisi ini mereka berkumpul bersama, makan bersama, dan berdoa bersama.

\subsection{Sebagai Perlindungan dari Penyakit atau Hama}

Serangkaian ritual Pethik Pari yang dilakukan setiap setahun juga bermakna sebagai perlindungan dari penyakit atau hama yang dapat mengganggu tanaman padi yang mempengaruhi hasil panen sehingga tidak merugikan petani. Para petani di desa Dukuh Dempok selalu melakukan kegiatan selamatan Pethik Pari tersebut. Karena masyarakat menganggap pelaksanaan selametan Pethik Pari tersebut sebagai tolak bala atau menjaukan musibah dari kehidupan para petani. Terutama menolak musibah gagal panen, sehingga hasil panen yang diperoleh melipah dan mendapat banyak rezeki untuk mencukupi kebutuhan sehari harinya. Selain beranggapan selamatan Pethik Pari sebagai penangkal musibah, masyarakat juga meyakini akan medapatkan rasa ketenangan, rezeki lancar, merasa dicukupkan tidak kekurangan, diberikan kesehatan serta dimudahkan dalam berbagai masalah. Apabila ketika melaksanakan selametan Pethik Pari hati merasa gembira dan senang, maka segala hal-hal negatif akan hilang.

\section{Interaksi Simbolik Pada Ritual Pethik Pari}

Terciptanya suatu interaksi yang memiliki makna dibalik suatu kegiatan pada ritual Pethik Pari membuat masyarakat mampu mengartikan dan berjejaring hubungan sosial. Ritual Pethik Pari saat ini yang dilaksanakan di desa Dukuh Dempok merupakan sebuah ide baru yang diusulkan oleh salah satu seorang ketua kelompok di daerah tersebut. Perbedaan dari sebelumnya praktek ritual Pethik Pari yang hanya dilaksanakan di rumah yang kemudian dirubah atau dimodifikasi sedikit dengan pelaksanaan berdoa bersama dengan masyarakat. Ritual ini menjadi wadah individualitas petani yang dicoba dibentuk ulang.

Kemampuan masyarakat dalam memahami simbol-simbol ritual Pethik Pari yang memiliki makna sosial yang sama, sehingga membuat individu petani harus dapat mengembangkan pikiran mereka melalui interaksi dengan individu lain yang terkandung dalam ritual Pethik Pari. Dengan pikiran ini lah maka muncul ide dari seorang individu yaitu salah seorang ketua kelompok di desa Dukuh Dempok untuk mengusulkan agar ritual Pethik Pari dilaksanakan bersama dengan masyarakat lainnya di sawah dan melaksanakan kegiatan secara bersama dalam sebuah acara kesenian atau yang lainnya.

Usulan dari salah seorang ketua kelompok merupakan hasil dari sebuah refleksi diri ritual Pethik Pari sebelumnya yang dilakukan masyarakat Dukuh Dempok. Interaksi simbolik tidak terlepas dari diri atau individu itu sendiri. Dari hasil sebuah refleksi diri atau individu petani ini lah sehingga individu petani yang lain dapat memahami dan menerima dari usulan yang merupakan hasil dari melihat kembali ritual sebelumnya.

Masyarakat petani di Dukuh Dempok memiliki jejaring hubungan sosial yang baik. Hal tersebut dapat dilihat dalam ritual Pethik Pari. Individu-individu petani dan masyarakat lainnya turut ikut serta dalam ritual Pethik Pari. Mereka dengan aktif dan sukarela mengikuti acara tersebut, 
karena mayarakat tersebut telah meyakini atau menyepakati isi dari ritual Pethik Pari. Ritual Pehik Pari yang sangat syarat dengan makna dan dari makna tersebut masyarakat petani dan lainnya di Dukuh Dempok dapat memahami dan merefleksikan hal-hal yang terkadung didalamnya bermanfaat bagi kehidupan sosial disana. Dari proses tersebutlah akhirnya individu petani dan lainnya dapat mengambil peran dalam ritual Pethik Pari di tengah masyarakat desa Dukuh Dempok.

\section{Kesimpulan}

Masyarakat Desa Dukuh Dempok, Kecamatan Wuluhan, Jember khususnya para petani masih mempertahankan tradisi ritual Pethik Pari yang merupakan budaya orang Jawa. Ada tiga tahapan dalam Pethik Pari, yaitu yang pertama selametan yang dilakukan setelah selesai menanam padi dinamakan entas-entas sawah. Kedua, rujakan atau ngrujak-i dimana ketika padi mulai menguning, masyarakat desa Dukuh Dempok akan membuat rujak yang dinamakan rujak ceprot. Ketiga, ketika satu minggu sebelum panen, para petani akan melakukan prosesi methik untuk mboyong atau membawa pulang Dewi Sri secara simbolis ke lumbung padi. Berkaitan dengan prosesi atau cara pelaksanaan ritual Pethik Pari, dahulu ritual Pethik Pari ini dilakukan oleh para petani di rumah masing-masing. Sekarang prosesi ritual Pethik Pari mengalami perubahan dan dilaksanakan tidak hanya oleh para petani, akan tetapi dilaksanakan secara bersama-sama dengan semua lapisan masyarakat tanpa memandang profesi, mulai dari anak kecil, ibu-ibu, bahkan sampai para pejabat hadir untuk melaksanakan ritual Pethik Pari tersebut. Dalam hal ini, Pethik Pari sebagai suatu ritus tradisi masyarakat petani Jawa menjadi pembentuk ulang individualitas petani di Desa Dukuh Dempok.

Hal yang juga menarik dalam ritual Pethik Pari di Desa Dukuh Dempok ini, masyarakat menanggap bahwa Wayang tidak hanya sekedar tontonan, tetapi juga sebagai tuntunan yang dicontoh oleh semua masyarakat. Selain itu, mereka juga melepas ikan untuk memancing bersama-sama sebagai hiburan. Dengan masih dilaksanakannya ritual Pethik Pari di Desa Dukuh Dempok ini menandakan bahwa tradisi Jawa yang mulai luntur dijaman modern ini, masyarakat di desa Dukuh Dempok, kecamatan Wuluhan, Jember masih berupaya melestarikannya.

\section{Daftar Pustaka}

Ardianto, E. (2007). Filsafat Ilmu Komunikasi. Bandung: Simbiosis Rekatama Media.

Dani, R .2016.Kamus Sosiologi.Diakses melalui situs https://id.scribd.com/doc/290667124/Kamu s-Sosiologi-a-z pada tanggal 06 Juni 2020

Endraswara, S. (2006). Mistik Kejawen (Sinkretisme, Simbolisme, dan Sufisme dalam Budaya Spiritual Jawa). Yogyakarta: Gadjah Mada University Press.

Geertz, C. (2013). Agama Jawa: Abangan, Santri, dan Priyadi dalam Kebudayaan Jawa. Depok: Komunitas Bambu.

Koentjaraningrat. (1979). Masalah-masalah Pembangunan: Bunga Rampai Antropologi Terapan. Jakarta: LP3ES.

Koentjaraningrat. (2009). Pengantar Ilmu Antropologi. Jakarta: PT Renika Cipta.

Masrizal. (2019). Pengendalian Masalah Sosial Melalui Kearifan Lokal. Banda Aceh: Percetakan \& Penerbit Syiah Kuala Lumpur University Press.

Raco, J. (2013). Metode Penelitian Kualitatif: Jenis, Karakteristik dan Keunggulannya. Jakarta: Grasindo.

Ritzer, G. (2016). Sosiologi Ilmu Pengetahuan Berparadigma Ganda. Jakarta: PT RajaGrafindo Persada.

Sasongko, T. H. (2006). Potret Petani: Basis Pembaruan Agraria. Bandung: Yayasan AKATIGA.

Shanin, T. (1975). Peasants and Peasant Societies.

Siregar, N. S. (2011). Kajian tentang Interaksionisme Simbolik. Kajian tentang Interaksionisme Simbolik, 105.

Soekanto, S. (2006). Sosiologi Suatu Pengantar. Jakarta: PT Raja grafindo Persada.

Soekanto, S. (2007). Sosiologi Suatu Pengantar. Jakarta: PT Raja grafindo Persada.

Yusuf, A. M. (2014). Metode Penelitian: Kuantitatif, Kualitatif, Dan Penelitian Gabungan. Jakarta: Kencana. 